\title{
Dynamics of physical fitness changes in preschool children, schoolgirls and female students of Eastern Siberia (Russia)
}

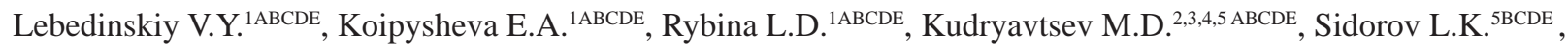 \\ Zukanov N.N. ${ }^{4 \mathrm{BCDE}}$, Doroshenko S. A. ${ }^{2 \mathrm{BCDE}}$, Kondratyuk T. A. ${ }^{5 \mathrm{BCDE}}$, Alshuvaili H. H. ${ }^{2,6 B C D E}$ \\ ${ }^{1}$ Department of Physical Culture, Irkutsk National Research Technical University, Russia \\ ${ }^{2}$ Department of Valeology, Department of Physical Culture, Siberian Federal University, Russia \\ ${ }^{3}$ Department of Physical Education, Reshetnev Siberian State University of Science and Technology, Russia \\ ${ }^{4}$ Department of Physical Training, The Siberian Law Institute of the Ministry of Internal Affair of Russia, Russia \\ ${ }^{5}$ Department of Theoretical Foundations of Physical Education, Krasnoyarsk State Pedagogical University of V.P. \\ Astafyev, Russia \\ ${ }^{6}$ Iraqi Football Association, Iraq
}

Authors’ Contribution: A - Study design; B - Data collection; C - Statistical analysis; D - Manuscript Preparation; E - Funds Collection.

\begin{abstract}
Purpose: $\quad$ the analysis of physical fitness dynamics of the preschool children, schoolgirls and female students living in the region with an intense ecological situation.

Material: $\quad$ In total were surveyed: 1580 preschool children (age 4-7 years), 3211 schoolgirls (age 7-17 years) and 5827 female students (age 17-21 years). It was applied physical fitness tests of various groups of Russia population.

Results: It was determined three essential periods of the main characteristics changes of physical fitness. The preschool age is characterized by the expressed gain of results. The lowest characteristics were revealed in senior age (after $17-18$ years). Female students have relative stabilization value of these indicators.

Conclusions: it is necessary to change the content of the educational process of physical training in educational institutions of the region.

Keywords: $\quad$ preschool children, schoolgirls, female students, physical fitness.
\end{abstract}

\section{Introduction}

Increase in the level of physical fitness - is one of the most important tasks. They have to be solved in the course of physical training of younger generation in general [1] and also of preschool children [2], school pupils [3] and female students [4]. The health of each nation in many respects depends on the efficiency of its solving. Physical conditions of children [5] and young people considerably determine the level of their health [6]. It is extremely important to understand and to estimate correctly physical fitness of modern preschool children, schoolgirls and female students [7]. The factor of strengthening of the pedagogical orientation of physical training of students at the non-major universities is especially relevant now. Such universities don't train future experts in physical culture and sport [8].

The physical fitness is the result of physical training to a certain kind of activity. This process is characterized by the level of development of the main quality for this activity (endurance, force, dexterity, flexibility, speed). The degree (high, average, low) of their mastering is also very important [9]. The process of assessment of this level has to be based on the comparison of testing results to standards. It is necessary to consider the dynamics of a gain of individual characteristics in each age group [10].

Pedagogically purposeful impact on the development of physical qualities is very important [11]. It is performed in indissoluble correlation with training in physical

\footnotetext{
(C) Lebedinskiy V.Y., Koipysheva E.A., Rybina L.D.,

Kudryavtsev M.D., Sidorov L.K., Zukanov N.N.,

Doroshenko S. A., Kondratyuk T. A., Alshuvaili H. H., 2018

doi:10.15561/20755279.2018.0503
}

capacities. This process is directed at promoting the full display of physical qualities. Their progress is shown at different steps of age development. This role is especially essential to successful mastering motor skills. It is very important to add and to correct impact of physical work on the development of physical qualities [12]. The main content of the first initial training is a comprehensive physical education of preschool children. It is necessary to control children's mastering of basic techniques of physical exercises performance [13].

Characteristics of children's physical activity are collected on a basis of examination of homogeneous groups of children. Children live in a certain region. All this is the basis for calculation of their physical fitness standards. These standards can be considered the most important tool of primary control over a condition of physical health of the younger generation [14]. The objective assessment of physical fitness is very important. It is necessary to consider the regularities of preschool children develop in the motor sphere.

Many researchers have described differences in parameters of children physical fitness of different regions of Russian Federation (RF). It is theoretically proved the need of introduction, so-called large zone standards at the level of the big region (territory, area) [15]. It is supposed introduction of separate regional assessment standards at the city level.

Nowadays in Eastern Siberia region is applied only the all-Russian standards for assessment of children's motor qualities. Irkutsk region (Irkutsk city) has been chosen as one of five basic platforms. Collecting and processing of materials for monitoring researches have been organized 
[16]. Development of performing technology was carried out. Examinations of physical development and physical fitness of various age and gender groups of the population were conducted [17].

The monitoring system is actively developed in Russian Federation nowadays [18]. It allows to perform the analysis, assessment, and prediction of the physical health condition of preschool children, school students, female students. Also, it is possible to develop hygienic standards of physical activities and correctional programs for them. These actions are directed to the strengthening of health and characteristics improvement of physical fitness of the younger generation. Also, it is necessary to improve the forms and methods of their physical training [19].

In the different countries is the actual need for modern studying of specific features of youth [20]. It is performed at physical culture training and different kinds of sport [21]. Researchers pay the closest attention to the choice of optimum physical activities [22] on an organism engaged [23]. Loading corresponds to opportunities of an organism of athletes [24]. Determination of health condition [25] is always very relevant direction for the scientists of different countries. A lot of attention is paid to maintenance of optimum health level of the population.

Within application of physical health monitoring in various regions of Russian Federation was performed a study of physical fitness characteristics of various groups of the population, for example, pupils of Moscow schools (Russia) [26]. The analysis of physical fitness condition of pupils of schools of Yekaterinburg and Sverdlovsk region (Russia) has been made [27]. It was performed the analysis of physical fitness monitoring of school pupils of Khanty-Mansi Autonomous Okrug (Russia) [28]. It was applied scientific-technological support of the social and pedagogical design of health condition monitoring system of different groups of a population of the KabardinoBalkar Republic (Russia) [29]. These researches demonstrated that there are age and gender differences. These differences are defined also by ethnonational peculiarities of the population.

It is also necessary to consider the influence of climatic conditions on the development of children motor abilities. It is necessary to consider in the training of future teachers physical culture [30]. The Australian researchers pay special attention to the study and creation of programs of physical training [31]. The youth has to demonstrate a special approach to positive attitude formation towards own health [32] in sports activities [33]. It is very important in the choice and receiving sports education [34].

Hypothesis. The research of the physical fitness of preschool children, schoolgirls, and female students will allow to increase the efficiency of their physical training.

Research purpose. To study physical fitness of children, teenagers and student's youth in the municipal preschool educational institutions (MPEI), in municipal educational institutions high comprehensive schools (MOI HCS) and in the higher educational institutions (HEI).

\section{Material and methods}

Participants: it was examined: 1580 preschool children at the age of 4-7 years (researches haven't included the children with chronic diseases) (Irkutsk, Russia); 3211 schoolgirls at the age of 7-17 years (Irkutsk, Russia); 5827 female students at the age of 17-21 years (1-4 year of study) (Irkutsk, Russia).

Organization of a research. It was applied tests of physical fitness of various groups of Russia population [35]. Researches were performed two times per year: at the beginning (September) and at the end (May) of the academic year (from September 2004 to May 2007). For girls (age 4-7 years) four tests were applied: on flexibility ("seated forward bend" test); on speed ("30 m run" test); on force - it was measured the dynamic force of girdle of inferior extremity muscles ("standing long jump" test); on high-speed and power endurance of flexors of the back ("Sit-ups in $30 \mathrm{~s}$ " test) [36, 37, 38].

The following tests were performed by schoolgirls and female students: for assessment of high-speed endurance and dexterity connected with change of the direction of the motion and alternation of acceleration and braking ("shuttle run" test); for assessment of force and static endurance of muscles of the girdle of superior extremity ("bent suspension" test); for measurement of active flexibility of a backbone and bending in coxofemoral joints ("seated forward bend" test); for measurement of high-speed and power endurance of flexors of the back ("Sit-ups in $30 \mathrm{~s}$ " test); for determination of the general endurance (1 $000 \mathrm{~m}$ run test - schoolgirls, 5 min run female students); for speed assessment (run tests: $20 \mathrm{~m}$ run - female students and $30 \mathrm{~m}$ run - schoolgirls); for measurement of dynamic force of girdle of inferior extremity ("standing long jump" test) [36, 37, 38].

Statistical analysis. It was applied the software of Microsoft Excel 7.1 and "Statistica 6.1". The statistical significance of the average values of independent samples was estimated by Student's t-test at $\mathrm{p}<0,05$.

\section{Results}

It is possible to trace the data shown in this publication (according to performed monitoring researches) at the age from 4 to 21 year (tab. 1).

It was revealed the changes in physical fitness characteristics in girls and female students of various age stages according to the results of the performed research.

It was performed the analysis of characteristics change of high-speed and power of body muscle endurance in examined persons (tab. 1, fig. 1). They can conditionally be divided into 4 stages:

- the 1st stage - the expressed rise (4-7 years) of indicator values - up to 7,6 times a year at the age up to 7 years;

- the 2nd stage - a moderate gain (8-11 years) of indicator values- up to 0,8 times a year at the age up to 11 years;

- the 3rd stage - a low gain (11-17 years) - up to 0,5 times a year;

- the 4th stage - decrease in values of the studied 
indicator to 1,1 time in a year (17-21 years).

The analysis of flexibility characteristics of a spinal column and bending in coxofemoral joints (fig. 2) shown that its changes proceed in five main stages:

- the 1 st stage - from 4 to 6 years. There are no essential changes;

- the 2nd stage - the expressed rise (7-11 years) of indicator values up to $1,5 \mathrm{~cm}$ a year;

- the 3rd stage - from 11-13 years appears wavy changes of characteristics. By age 12 years $(0,4 \mathrm{~cm}$ a year) there is an insignificant decrease in values. By age
13 years $(0,2 \mathrm{~cm}$ a year $)$ it increases again;

- the 4th stage - an intensive gain (14-18 years). At this stage, the minimum gain is in 15 years (to $0,2 \mathrm{~cm}$ a year), and maximum - is in 18 years (3,3 cm a year);

- the 5th stage - from 19 to 21 years. Characteristics of flexibility whether don't change (19 years) or slightly increase up to $0,3 \mathrm{~cm}$ a year.

The dynamic force of muscles of the lower extremities (fig. 3) can also conditionally be subdivided into the 5 th a stage:

- the $1^{\text {st }}$ stage - from 4 to 6 years - intensive (up

Table 1. Physical fitness of preschool children, schoolgirls, and female students

\begin{tabular}{|c|c|c|c|c|c|c|}
\hline Test $\quad$ Age (years) & 4 & 5 & 6 & 7 & 8 & 9 \\
\hline Sit-ups in $30 \mathrm{~s}$ (times) & $\begin{array}{l}4,3 \\
\pm 0,3\end{array}$ & $\begin{array}{r}5,5^{* *} \\
\pm 0,2\end{array}$ & $\begin{array}{l}8,0 * * \\
\pm 0,3\end{array}$ & $\begin{array}{l}15,6^{*} \\
\pm 0,4\end{array}$ & $\begin{array}{l}16,3^{* * *} \\
\pm 0,2\end{array}$ & $\begin{array}{c}18,0 * \\
\pm 0,2\end{array}$ \\
\hline Seated forward bend $(\mathrm{cm})$ & $\begin{array}{l}3,8 \\
\pm 0,4\end{array}$ & $\begin{array}{l}3,0 \\
\pm 0,3\end{array}$ & $\begin{array}{l}4,0 * * * \\
\pm 0,3\end{array}$ & $\begin{array}{l}5,5 * * * \\
\pm 0,6\end{array}$ & $\begin{array}{l}6,0 \\
\pm 0,3\end{array}$ & $\begin{array}{c}6,5 \\
\pm 0,3\end{array}$ \\
\hline Standing long jump (cm) & $\begin{array}{l}62,9 \\
\pm 1,2\end{array}$ & $\begin{array}{l}79,2 * \\
\pm 0,9\end{array}$ & $\begin{array}{l}93,5^{* *} \\
\pm 0,9\end{array}$ & $\begin{array}{l}100,3^{* * *} \\
\pm 2,0\end{array}$ & $\begin{array}{l}109,5^{*} \\
\pm 1,1\end{array}$ & $\begin{array}{l}120,8^{*} \\
\pm 1,0\end{array}$ \\
\hline Age (years) & 10 & 11 & 12 & 13 & 14 & 15 \\
\hline Sit-ups in $30 \mathrm{~s}$ (times) & $\begin{array}{l}19,9 * \\
\pm 0,2\end{array}$ & $\begin{array}{l}21,7^{*} \\
\pm 0,2\end{array}$ & $\begin{array}{l}22,2^{*} \\
\pm 0,1\end{array}$ & $\begin{array}{l}22,5 \\
\pm 0,2\end{array}$ & $\begin{array}{l}22,3 \\
\pm 0,2\end{array}$ & $\begin{array}{l}22,5 \\
\pm 0,2\end{array}$ \\
\hline Seated forward bend $(\mathrm{cm})$ & $\begin{array}{l}7,5^{* *} \\
\pm 0,3\end{array}$ & $\begin{array}{l}8,6^{*} \\
\pm 0,2\end{array}$ & $\begin{array}{l}8,2 \\
\pm 0,2\end{array}$ & $\begin{array}{l}8,8 * * * \\
\pm 0,2\end{array}$ & $\begin{array}{l}9,9 * \\
\pm 0,3\end{array}$ & $\begin{array}{l}10,1 \\
\pm 0,3\end{array}$ \\
\hline Standing long jump (cm) & $\begin{array}{l}135,4^{*} \\
\pm 0,9\end{array}$ & $\begin{array}{l}145,9 * \\
\pm 0,8\end{array}$ & $\begin{array}{l}154,2^{*} \\
\pm 0,7\end{array}$ & $\begin{array}{l}158,2^{*} \\
\pm 0,7\end{array}$ & $\begin{array}{l}163,4^{*} \\
\pm 0,7\end{array}$ & $\begin{array}{l}167,8^{*} \\
\pm 0,8\end{array}$ \\
\hline Age (years) & 16 & 17 & 18 & 19 & 20 & 21 \\
\hline Sit-ups in $30 \mathrm{~s}$ (times) & $\begin{array}{l}22,7 \\
\pm 0,2\end{array}$ & $\begin{array}{l}23,5^{* * *} \\
\pm 0,3\end{array}$ & $\begin{array}{l}22,5^{* * *} \\
\pm 0,1\end{array}$ & $\begin{array}{l}22,8^{* *} \\
\pm 0,01\end{array}$ & $\begin{array}{l}22,5^{* * *} \\
\pm 0,1\end{array}$ & $\begin{array}{l}21,6 * * \\
\pm 0,2\end{array}$ \\
\hline Seated forward bend $(\mathrm{cm})$ & $\begin{array}{l}11,2 \\
\pm 0,3\end{array}$ & $\begin{array}{l}12,5^{*} \\
\pm 0,5\end{array}$ & $\begin{array}{l}15,8 * * * \\
\pm 0,1\end{array}$ & $\begin{array}{l}15,8^{*} \\
\pm 0,1\end{array}$ & $\begin{array}{l}16,1 \\
\pm 0,2\end{array}$ & $\begin{array}{l}16,4 \\
\pm 0,3\end{array}$ \\
\hline Standing long jump (cm) & $\begin{array}{l}169,1 \\
\pm 1,1\end{array}$ & $\begin{array}{l}171,8 \\
\pm 1,4\end{array}$ & $\begin{array}{l}156,9 * \\
\pm 0,4\end{array}$ & $\begin{array}{l}157,0 \\
\pm 0,1\end{array}$ & $\begin{array}{l}155,4^{* * *} \\
\pm 0,5\end{array}$ & $\begin{array}{l}156,0 \\
\pm 0,9\end{array}$ \\
\hline
\end{tabular}

$* \mathrm{P}<0,001, * * \mathrm{P}<0,01, * * * \mathrm{P}<0,05$, in relation to the previous age.

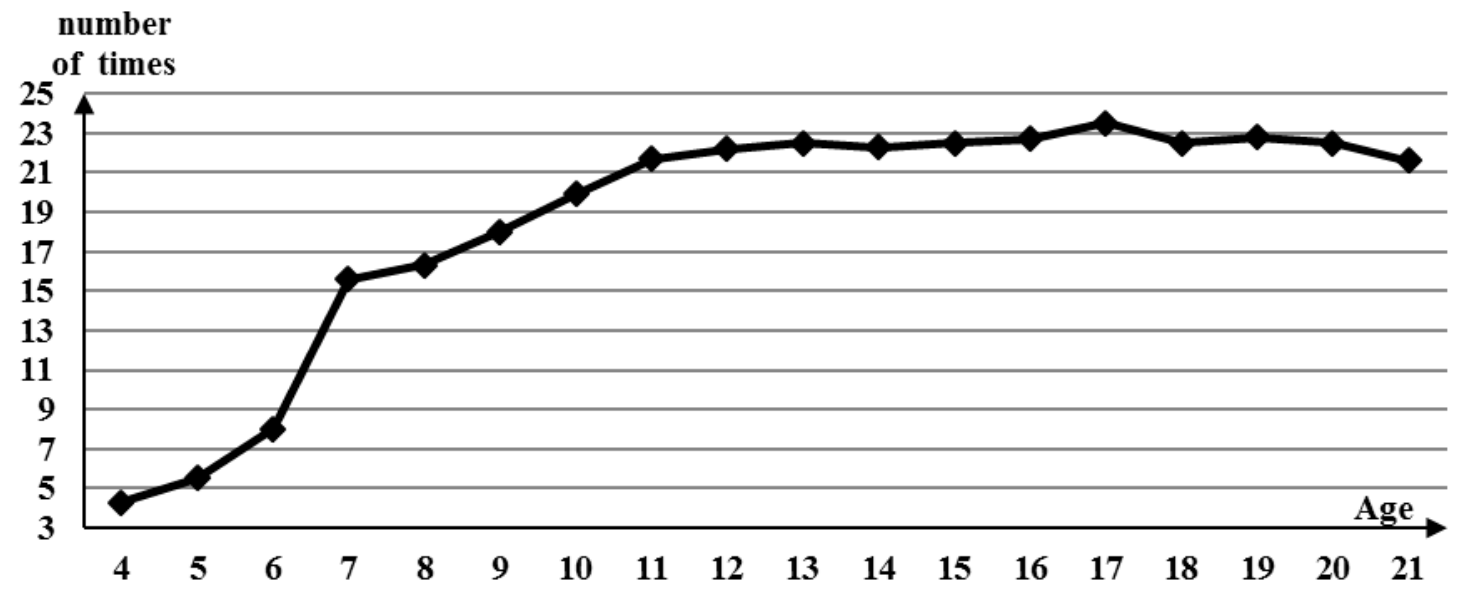

Fig. 1. Results of performing the test "Sit-ups in $30 \mathrm{~s}$ " 
to $16 \mathrm{~cm}$ a year) development of characteristics of this indicator;

- the $2^{\text {nd }}$ stage - moderated (4-14 $\mathrm{cm}$ a year) development at the age of 7-12 years. It should be noted that at the age of 9-12 years it is more expressed (9-14 cm a year);

- the $3^{\text {rd }}$ stage - a moderate gain (from 13-17 years);

- the $4^{\text {th }}$ stage - the expressed decrease in indicator values (up to $15 \mathrm{~cm}$ a year by 18 years);

- the $5^{\text {th }}$ stage - stabilization (19-21 years).

Earlier we determined 5 stages of motor qualities development (high-speed and power endurance of body muscles, the flexibility of a spinal column and bending in coxofemoral joints, the dynamic force of girdle of inferior extremity muscles). Their main changes can be divided into 3 stages: 1st stage (preschool age). He is characterized by the expressed gain of results. At the 2nd stage (8-16, 17 years) it is defined their moderate gain which becomes more active during the sensitive periods. At the 3rd stage (girls senior to 16,17 years) is the insignificant gain of fitness or even its essential decrease.

It was considered the maximum and minimum values of the average level of their development in the construction of a diagram. According to the results of comparison the level of physical fitness of children from municipal preschool educational institutions (Irkutsk) [1] with children from other regions of Russian Federation [16] it was revealed: in the test "Standing long jump “ (fig. 4.) - regional values was worse only in 4 years girls; in other age categories they approach to the all-Russian standards, though remain at lower level. In 6 years girls from Irkutsk have little improvement of the low limits of values of these indicators in comparison with preschool children from other regions of Russian Federation.

In the test "Sit-ups in 30 s" (fig. 5) girls from Irkutsk have lower results, than their contemporary (Russian Federation) in 4-5 years. However in 6-7 years the upper limit of values of regional indicators accrues and comes nearer to all-Russian, and their lower limit - has values significantly below.

The Irkutsk preschool children demonstrated the worst results at the age of 4-5 years in the "30 m run" test (fig. 6). However in 6-7 years they improve values of this indicator to the level of their equals in age from other regions. In 6 years Irkutsk preschool children improve the upper limits of this indicator.

In school-age children of Irkutsk, the better results of speed testing (“30 m run”, fig. 7) were at all age.

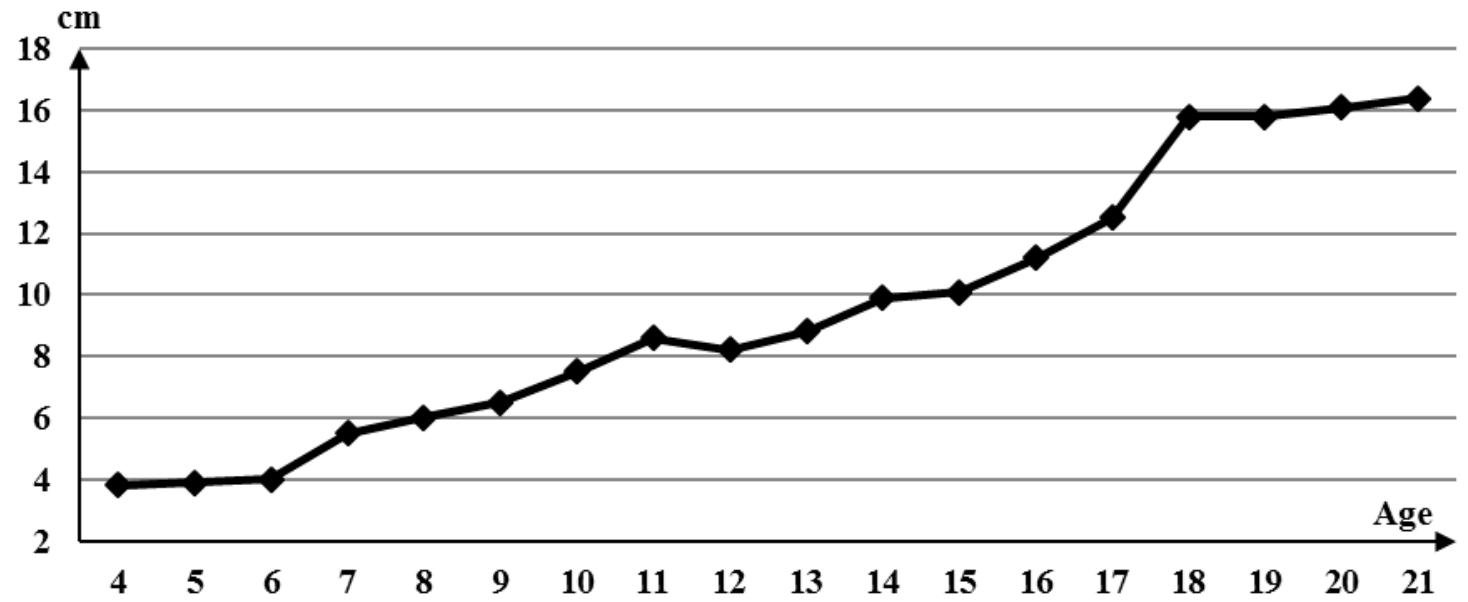

Fig. 2. Results of performing the test "Seated forward bend"

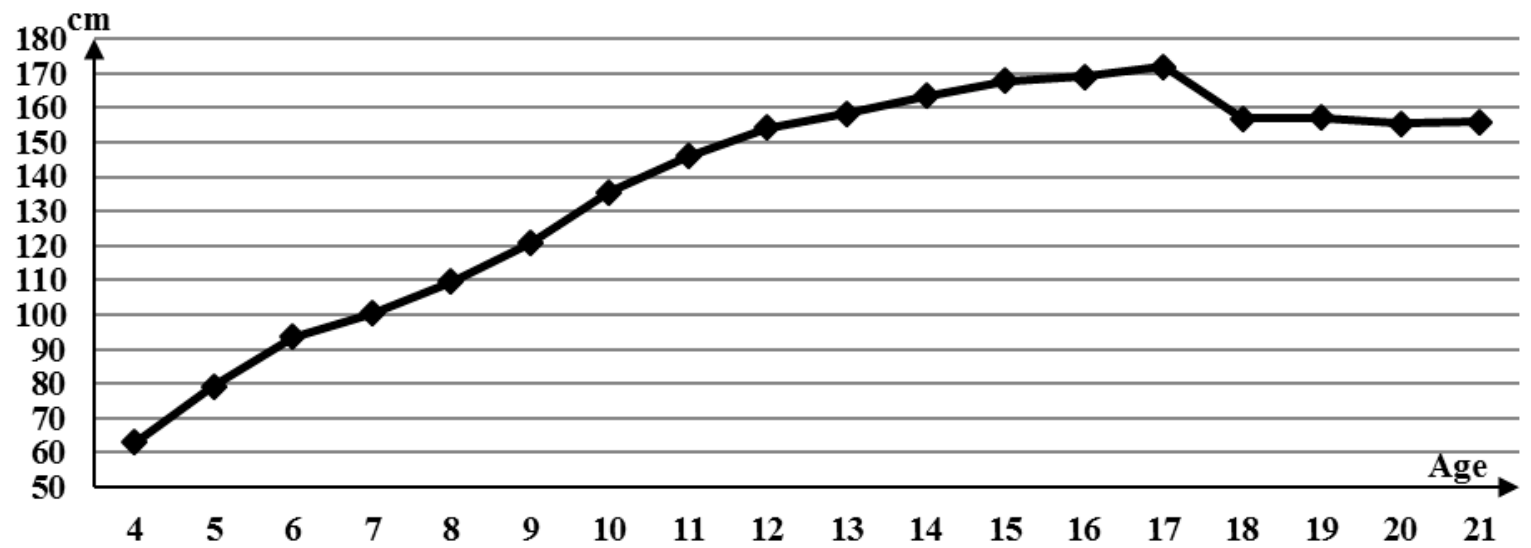

Fig. 3. Results of performing the test "Standing long jump" 


\section{$\mathbf{c m}$}

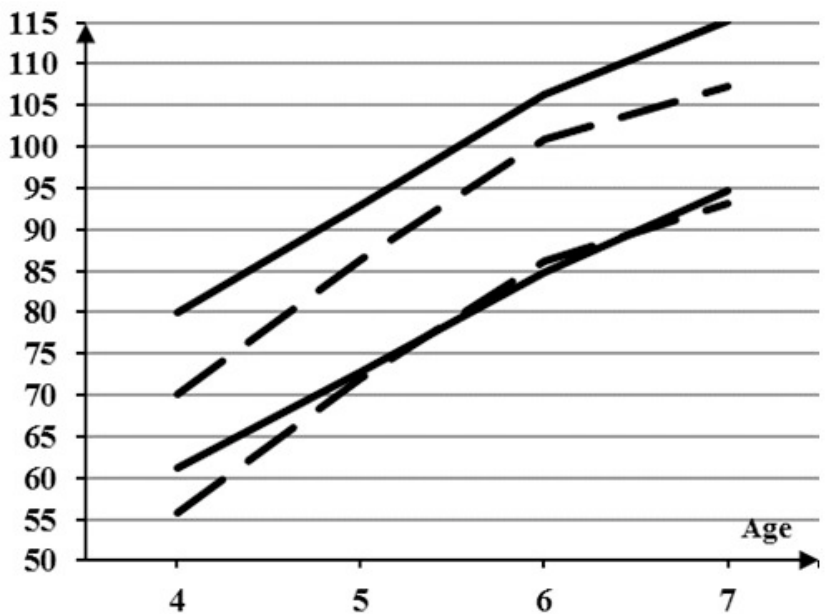

Fig. 4. Results of performing the test «Standing long jump» number

of times

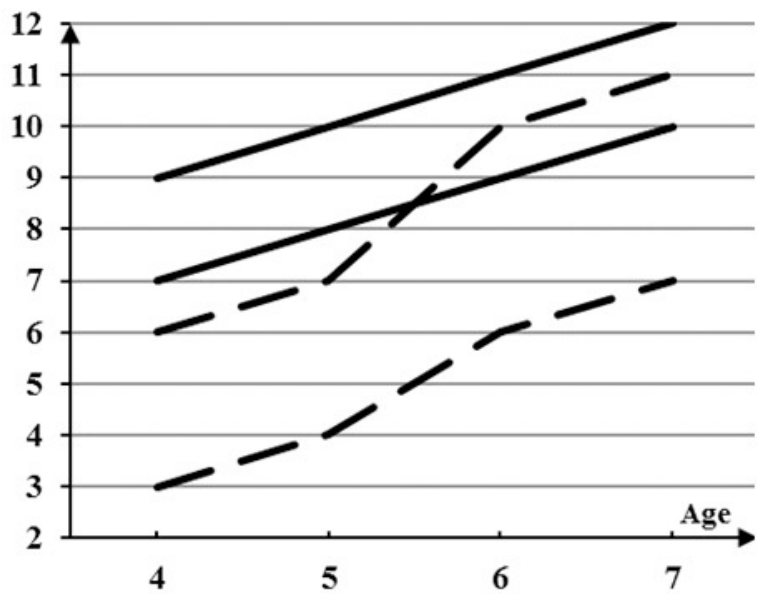

Fig. 5. Results of performing the test «Sit-ups in 30 s»

- - - average level of preschool children and pupils of the municipal educational institution of Irkutsk

- the average level of preschool children and pupils according to the all-Russian standard.

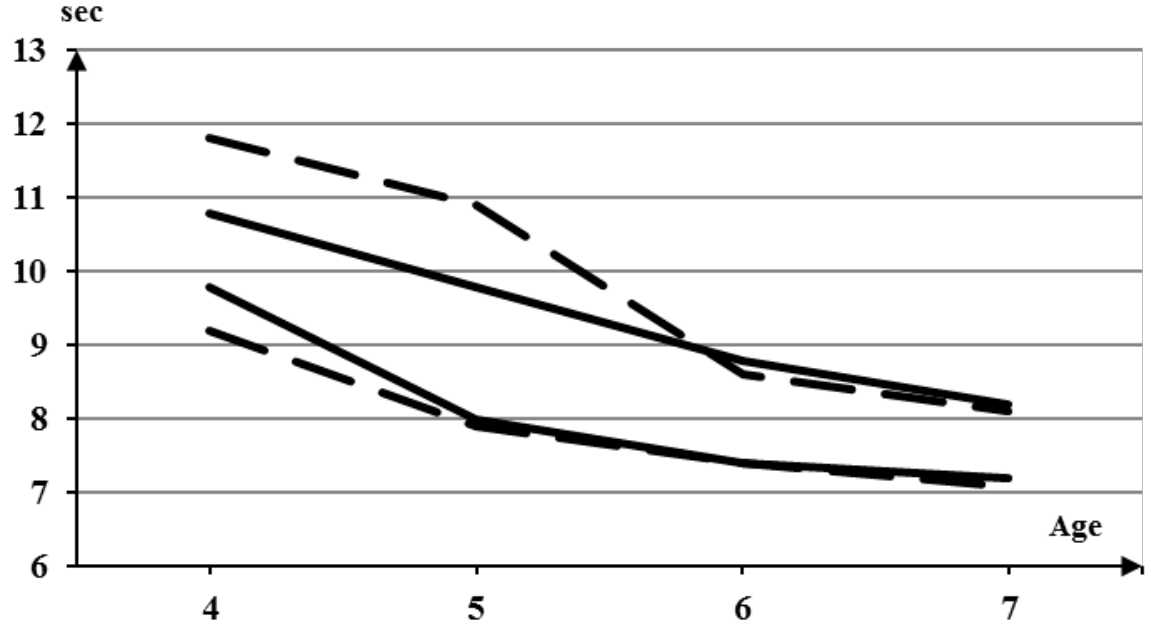

Fig 6. Results of performing the test " 30 m run"

- - - average level of preschool children and pupils of municipal educational institutions of Irkutsk

- the average level of preschool children and pupils according to the all-Russian standard.

The test result on the assessment of the dynamic force of the girdle of inferior extremity muscles ("Standing long jump ", fig. 8) was almost identical in both compared groups. At the age of 7 and 8 years, it was slightly worse in Irkutsk schoolgirls.

In the test for determination of flexor muscle force ("Sit-ups in 30 s", fig. 9) pupils of Irkutsk have higher results at all age groups.

The analysis of test results on the determination of the general endurance ("1000 m run", fig. 10) has shown that girls of Irkutsk from 7 to 12 years only have better characteristic. Then their values become worse, and in 15-17 years advantage of results have Russians.

In considering and comparing of motor qualities characteristics in pupils of Irkutsk schools and the allRussian standards it was revealed that they are almost equal in testing muscles dynamic force of the girdle of inferior extremity. In girls of Irkutsk at all age, it is better results of tests for speed assessment ("30 m run"). Besides, in 7-17 years they have a higher force of body flexor muscle ("Sit-ups in $30 \mathrm{~s}$ ").

\section{Discussion}

Experts support the necessity of carrying out monitoring and performance of physical fitness level assessment of children, teenagers, and youth of student's age. Such researches have to be performed during preschool and elementary education at schools. It is important to include as active as possible the physical fitness monitoring in the general assessment of the social and public life of the educational institution. Thus our research is coordinated with other scientific work [28]. It is also agreed with other 


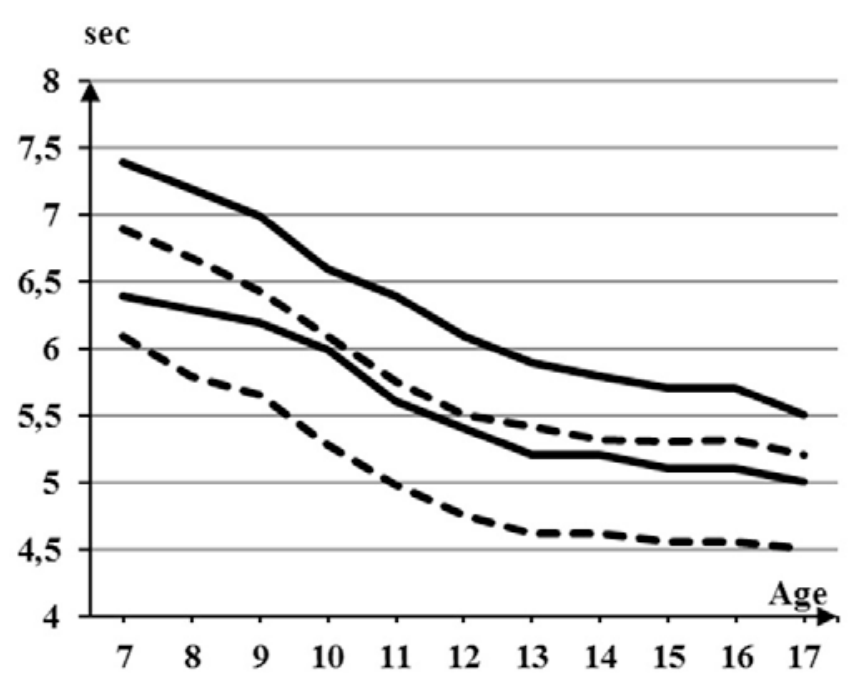

Fig. 7. Results of performing the test «30 m run»

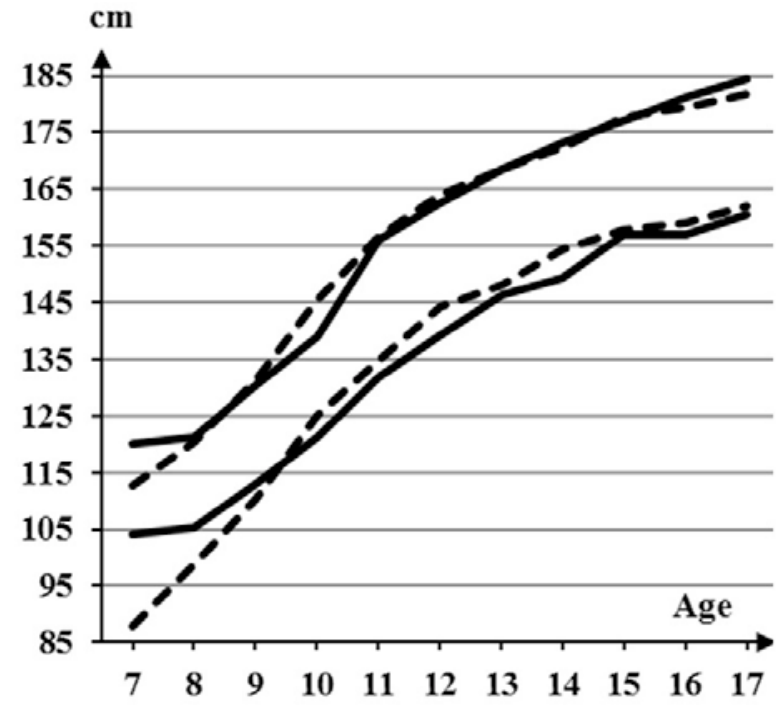

Fig. 8. Results of performing the test «Standing long jump»

- - - average level of preschool children and pupils of municipal educational institutions of Irkutsk

- the average level of preschool children and pupils according to the all-Russian standard.
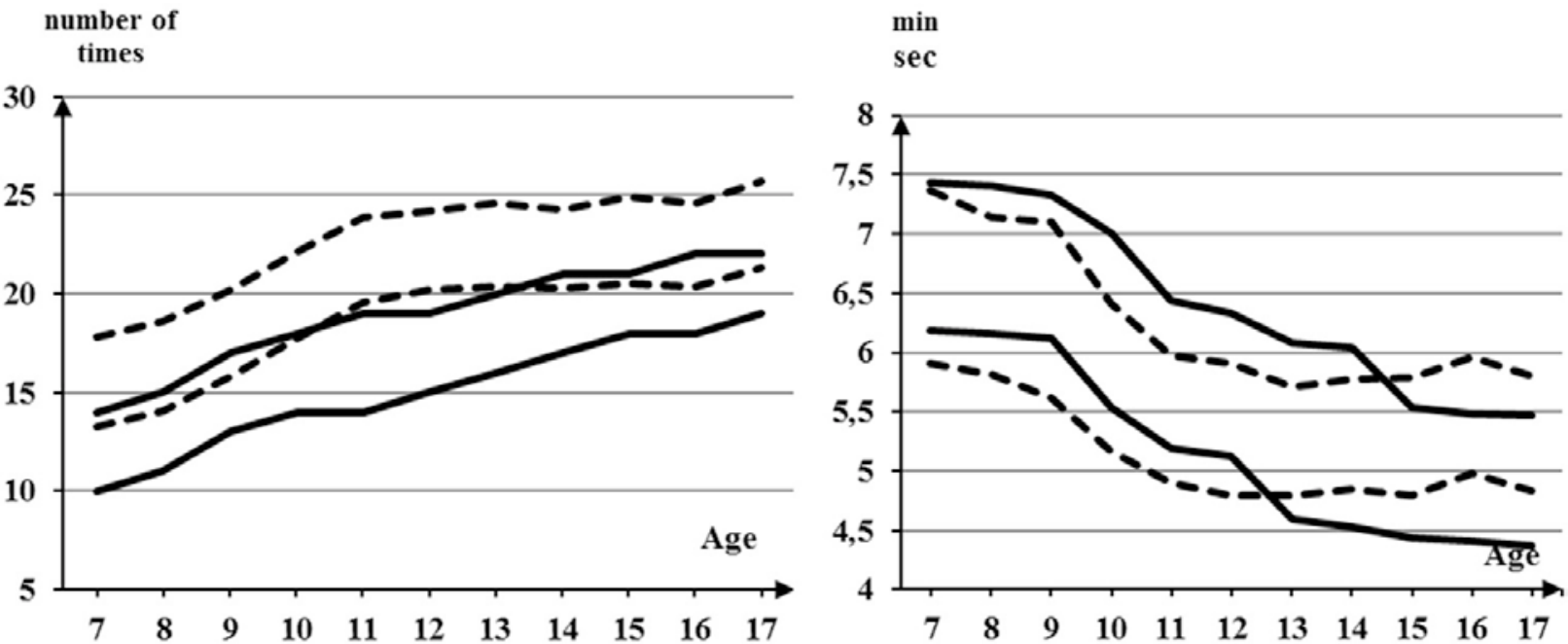

Fig. 9. Results of performing the test "Sit-ups in 30 s»

Fig. 10. Results of performing the test «1000 m run»

- - - average level of preschool children and pupils of municipal educational institutions of Irkutsk

- the average level of preschool children and pupils according to the all-Russian standard.

researches [26] in different regions of Russian Federation [27, 29]: monitoring implementation activities [14] of population physical health [18], physical development of children [2], teenagers [5], youth [4].

Improvement of physical training in school pupils [3] is directed to an increase in the level of their physical fitness [6]. Therefore this research doesn't conflict with the general tendencies [6] in the physical training of preschool children [16] and school pupils [15].

The solution of the task of health passport development [19] is agreed with the general [9] and regional settings [7]. Global distribution of a hypodynamia [20] and overweight in young people does this research even more demanded and relevant [30]. In this case, the position of authors of the article coincides with the opinion of a number of foreign experts [21]. For example, in a question of studying and increase in physical activity [31] of preschool children [23], elementary-school age children [24], teenagers and students [25]. Experts make the offers in the general concept of the increase in level of youth health. It is implemented in training programs on physical training [30] among modern young people.

It was revealed some distinctions in comparison of regional standards of physical fitness with the all-Russian characteristics [16]. Perhaps, it is defined by population living conditions in Eastern Siberia [13].

It is possible to draw the following conclusions in comparison of regional standards of physical fitness 
of preschool children from Irkutsk with all-Russian characteristics: Irkutsk girls seriously concede to contemporaries from other regions according to the key indicators. Especially these distinctions are expressed at the age of 4-5 years in the tests "Sit-ups in $30 \mathrm{~s}$ " and "Standing long jump". However, from 6 to 7 years the borders of regional standards increase. Then they approach all-Russian, and according to speed value - coincide with them.

Our research of motor qualities of Irkutsk schoolgirls has allowed to draw the corresponding conclusions. It was revealed age features in the analysis of studying results of the motor qualities dynamics in girls and female students. Their intensive improvement is mainly in 9-11 years. Such tendency is characteristic for Irkutsk and of the Russian schoolgirls. In a number of characteristics, the advantage of all-Russian standards is defined only at the senior school age (15-17 years). The differences between the results of the compared groups are minimized at the younger age. It is revealed that extent of motor qualities development (limit of the average level) in them coincides with all-Russian standards according to the majority of the studied indicators. However, girls from Irkutsk have authentically higher values of high-speed and power endurance of body muscles.

In the meantime, for increasing in level of physical fitness of preschool children, schoolgirls and female students requires the development of qualitatively new approaches. It is important that these approaches corresponded to each age and social group at the level of a class or student's group. Training to increase the physical fitness level have to take place according to educational programs in each concrete educational institution. It is especially important to consider age features of preschool children, schoolgirls, and female students.

\section{Conclusions}

Results of a research allow to develop criteria for evaluation of effective work of instructors and physical culture teachers in the creation of educational process.

The received results are recommended to apply in teaching and educational activities at comprehensive and sports schools, on physical culture chairs of higher education institutions.

The database of examination results and the developed standards of physical fitness of Irkutsk girls and female students from 4 years to 21 years could serve as a ground for further scientific research of physical fitness of various groups of the population.

\section{Conflict of interests}

The author declares that there is no conflict of interests.

\section{References}

1. Koipysheva EA, Rybina LD, Lebedinskiy VY. Physical condition and physical fitness of pre school age girls, schoolgirls and girl students of Irkutsk. Teoriia i praktika fizicheskoj kul'tury. 2016;4:41-43. (in Russian)

2. Gerasimova IN, Larina MV, Lebedinskiy VY, Sidorova IIu. Physical condition and physical fitness of Itkutsk children population: pre school age children. Irkutsk: ISTU; 2012. (in Russian)

3. Zav'ialov AI. Perfection of schoolchildren's physical education. Irkutsk; 2007. (in Russian)

4. Koipysheva EA. Dynamic of technical HEE girl students' physical development (second functional health group). Vestnik IrGTU, 2013;4(75):254-261. (in Russian)

5. Komkov AG. Social-pedagogic monitoring of physical activity, health and cultural development indicators. Teoriia $i$ praktika fizicheskoj kul 'tury, 1998;6:2-7. (in Russian)

6. Lubysheva LI, Malinin AV. Study of Russian schoolchildren's health and behavior. Fizicheskaia kul'tura: vospitanie, obrazovanie, trenirovka. 2004;6:16-22. (in Russian)

7. Lebedinskiy VY. Physical development of pre school age girls, school girls and girl students. Irkutsk: IRNITU Publ.; 2016. (in Russian)

8. Lebedinskiy VY. Monitoring of physical health as factor of physical education's pedagogic orientation strengthening in non profile HEEs. Teoriia i praktika fizicheskoj kul'tury, 2014;10:98-101. (in Russian)

9. Tiapin AN. Physical culture passport: methodic recommendations on test program. Moscow: VNIIFK; 1998. (in Russian)

10.Landa BKh. Methodic of physical condition and physical fitness complex assessment. Kazan; 2000. (in Russian)

11.Epifanova MG. Monitoring of girl students' physical condition and physical fitness. Irkutsk: IrSTU Publ.; 2014. (in Russian)
12.Ignat'eva EP. Physical condition and physical fitness of third functional health group's students. Irkutsk: IrSTU Publ.; 2014. (in Russian)

13.Sidorova IIu, Gerasimova IN, Larina MV, Lebedinskiy VY. Physical condition and physical fitness of Itkutsk children population: school children. Irkutsk: ISTU; 2012. (in Russian)

14.Izaak SI. Monitoring of physical condition and physical fitness. Moscow: Soviet sport; 2005. (in Russian)

15.Izaak SI, Lebedinskiy VY. Organization of rising generation's mass health examinations in Irkutsk region. International scientific methodic conference "Physical culture and sports in development of health formation and health protection technologies, "East-Russia-West", Irkutsk; 2005. P. 198201. (in Russian)

16.Kuchma VR. Health indicators of children and adolescents in modern system of social hygienic monitoring Gigiena $i$ sanitariia. 2004;6:14-16. (in Russian)

17.Rybina LD. Analysis of technical HEE girl students' physical condition during academic year (first functional health group). Vestnik Irkutskogo gosudarstvennogo tekhnicheskogo universiteta, 2014;2(85):312-316. (in Russian)

18.Vinogradov PA. Functioning of Goskomsport of Russia on population, children's, adolescents' and youth's physical health monitoring. Moscow; 2002. (in Russian)

19.Lebedinskiy VY. Monitoring of HEE educational processes' subjects health "Health Passport". Irkutsk: IrSTU Publ.; 2008. (in Russian)

20.Jagiello W. Differentiation of the body composition in taekwondo-ITF competitors of the men's Polish national team and direct based athletes. Archives of Budo. 2015;11:329-38.

21.Kolling S, Wiewelhove T, Raeder C, Endler S, Ferrauti A, Meyer T, et al. Sleep monitoring of a six-day microcycle in strength and high-intensity training. European Journal of Sport Science. 2016;16(5):507-15. 
22.Leonska-Duniec A, Grzywacz A, Jastrzebski Z, Jazdzewska A, Lulinska-Kuklik E, Moska W, et al. ADIPOQ polymorphisms are associated with changes in obesityrelated traits in response to aerobic training programme in women. Biology of Sport. 2018;35(2):165-173. doi:10.5114/ biolsport.2018.72762

23.Hastie PA, Rudisill ME, Boyd K. An ecological analysis of a preschool mastery climate physical education programme. Physical Education and Sport Pedagogy. 2016;21(2):217-32.

24.Khudolii OM, Ivashchenko OV, Iermakov SS, Rumba OG. Computer simulation of Junior gymnasts' training process. Science of Gymnastics Journal, 2016;8(3):215-228.

25.Manolachi V. Theory and Practice of Women's Sport (Evaluation, Planning, Direction and Nutrition). Monograph. Bucharest: Discobolul; 2018.

26.Tiapin AN, Shcherbakov VP, Golovkin IuV. Forms of the static reporting during physical fitness testing of pupils in educational institutions of Moscow. Moscow; 1998. (in Russian)

27.Semenov LA. The analysis of condition of standard physical fitness of schools pupils of Yekaterinburg and Sverdlovsk region. Scientific conference "Modern Problems of Physical Training in Educational Institutions”. Ekaterinburg; 2000. P.13-15. (in Russian)

28. Obukhov SN, Barabanshchikov AA. Monitoring of physical fitness of school pupils of Khanty-Mansi Autonomous Okrug. Work experience in territorial entity of the $R F$ on implementation of monitoring of physical health condition of children, teenagers and youth, 2002;1:123-128. (in Russian)

29.Indreev MKh. Scientific technological support of socialpedagogical design of monitoring system of division and health condition of different groups of the population of KBR. Scientific conference "Physical Culture and Sport in
Development of Health Promotion Technologies". Irkutsk; 2005. P. 125-128. (in Russian)

30.MacLean J, Mulholland R, Gray S, Horrell A. Enabling curriculum change in physical education: the interplay between policy constructors and practitioners. Physical Education and Sport Pedagogy. 2015;20(1):79-96.

31. Young JA, Symons CM, Pain MD, Harvey JT, Eime RM, Craike MJ, et al. Role models of Australian female adolescents: A longitudinal study to inform programmes designed to increase physical activity and sport participation. European Physical Education Review. 2015;21(4):451-66.

32.Korobeynikov G, Mazmanian K, Korobeynikova L, Jagiello W. Psychophysiological states and motivation in elite judokas. Archives of Budo. 2010;6(3):129-36.

33.Jagiello W, Kruszewski A. Morphological diversification of competitors training Greco-Roman style of wrestling. Archives of Budo. 2009;5:147-153.

34.Hastie PA, Wellhead T. Models-Based Practice in Physical Education: The Case for Sport Education. Journal of Teaching in Physical Education. 2016;35(4):390-9.

35.Lebedinskij VIu, Kolokol'cev MM, Maslova ES, Mel'nikova NS, Shporin EG. The health monitoring of educational processes entities in higher education institutions "Passport of health". Irkutsk: Irkutsk State Technical University Publ.; 2008. (in Russian)

36.Liakh VI. Physical culture. Test control. 10-11 forms. Education; 2012. (in Russian)

37.Physical Best. Physical Best activity guide - elementary level. Champaign IL: Human Kinetics; 1999.

38.The President's Challenge Physical Activity and Fitness Awards. The President's Challenge. [Internet] 2006 Nov 1 [updated 2007 Jan 1; cited 2018 Apr 8]. Available from: http://www.presidentschallenge.org. 10.03.2006 
Information about the authors:

Lebedinskiy V. Y.; http://orcid.org/0000-0002-5291-8775; lebedinskiy@istu.ru; Irkutsk National Research Technical University; 83 Lermontov St., 664074, Irkutsk, Russia.

Koipysheva E. A.; http://orcid.org/0000-0003-4058-5085; koip00@mail.ru; Irkutsk National Research Technical University; 83 Lermontov St., 664074, Irkutsk, Russia.

Rybina L. D.; http://orcid.org/0000-0003-3666-1946; rybina.liuda2016@yandex.ru; Irkutsk National Research Technical University; 83 Lermontov St., 664074, Irkutsk, Russia.

Kudryavtsev M. D. (Corresponding author); http://orcid.org/0000-0002-2432-1699; kumid@yandex.ru; Siberian Federal University: 79 Svobodny pr., Krasnoyarsk, 660041, Russia.; Reshetnev Siberian State University of Science and Technology; Office A-406, 31 , Krasnoyarsky Rabochy Av., 660014, Krasnoyarsk, Russia; Krasnoyarsk State Pedagogical University of V.P. Astafyev; Ada Lebedeva Street, 89, Krasnoyarsk, 660049, Russia; The Siberian Law Institute of the Ministry of Internal Affair of Russia; Rokossovskia str. 20, Krasnoyarsk, 660131, Russia.

Sidorov L.K.; http://orcid. org/0000-0002-4337-8201; sidorovk@kspu.ru; Krasnoyarsk State Pedagogical University of V.P. Astafyev; Ada Lebedeva Street, 89, Krasnoyarsk, 660049, Russia.

Zukanov N. N.; http://orcid.org/0000-0003-4476-6772; Nikolai Zukanov@mail.ru; The Siberian Law Institute of the Ministry of Internal Affair of Russia; Rokossovskia str., 20, Krasnoyarsk, 660131, Russia.

Doroshenko S. A.; http://orcid.org/0000-0002-8593-1685; trisha246@yandex.ru; Siberian Federal University; 79 Svobodny pr., Krasnoyarsk, 660041, Russia.

Kondratyuk T. A.; http://orcid.org/0000-0002-3770-6336; kondr1607@mail.ru; Krasnoyarsk State Pedagogical University of V.P. Astafyev; Ada Lebedeva Street, 89, Krasnoyarsk, 660049, Russia.

Alshuvaili H. H.; http://orcid.org/0000-0001-5044-592X; hassoo.nhashim@yahoo.com; Siberian Federal University; 79 Svobodny pr., Krasnoyarsk, 660041, Russia.; Iraqi Football Association; Zayouna, Al-Shaab Stadium, Baghdad, Iraq.

Cite this article as: Lebedinskiy VY, Koipysheva EA, Rybina LD, Kudryavtsev MD, Sidorov LK, Zukanov NN, Doroshenko SA, Kondratyuk TA, Alshuvaili HH. Dynamics of physical fitness changes in preschool children, schoolgirls and female students of Eastern Siberia (Russia). Physical education of students, 2018;22(5):243-251. doi:10.15561/20755279.2018.0503

The electronic version of this article is the complete one and can be found online at: http://www.sportedu.org.ua/index.php/PES/issue/archive

This is an Open Access article distributed under the terms of the Creative Commons Attribution License, which permits unrestricted use, distribution, and reproduction in any medium, provided the original work is properly cited (http://creativecommons.org/licenses/by/4.0/deed.en).

Received: 12.05.2018

Accepted: 12.06.2018; Published: 30.09.2018 